(c) American Dairy Science Association, 2003.

\title{
Effects of Different Levels of Gum Arabic, Low Methylated Pectin and Xylan on In Vitro Digestibility of $\beta$-Lactoglobulin
}

\author{
J. Mouécoucou, ${ }^{\star, 1}$ C. Sanchez,† C. Villaume,‡ O. Marrion, $\ddagger$ \\ S. Frémont,§ F. Laurent, ${ }^{\star}$ and L. Méjean* \\ *Laboratoire des Sciences Animales, ENSAIA-INPL, USC INRA, \\ F-54505 Vandoeuvre-lès-Nancy Cedex 5, France \\ †Laboratoire de Physico-Chimie et Génie Alimentaires, ENSAIA-INPL, \\ USC INRA, F-54505 Vandoeuvre-lès-Nancy Cedex 5, France \\ łLaboratoire de Pathologie Cellulaire et Moléculaire en Nutrition, \\ EMI 0014 INSERM and URM 20 IFREMER, Faculté de Médecine, \\ 54500 Vandoeuvre-lès-Nancy, France \\ §Laboratoire de Biochimie Médicale et Pédiatrique, Faculté de Médecine, \\ 54500 Vandoeuvre-lès-Nancy, France
}

\begin{abstract}
Plant hydrocolloids used in the food industry to improve texture and stability of food, such as dairy products, can reduce protein digestibility and, consequently, modify the bioavailability of amino acids. We studied the in vitro hydrolysis at $37^{\circ} \mathrm{C}$ of $\beta$-lactoglobulin $(\beta$-lg) in mixed dispersions containing either gum arabic or low-methylated pectin or xylan at levels of $0,1,10$, 20,30 , and $50 \%$ weight. Proteolysis used either pepsin alone by progressive reduction of $\mathrm{pH}$ during proteolysis or pepsin followed by trypsin and chymotrypsin in two different dialysis bags with a molecular weight (MW) cutoff of 1000 or $8000 \mathrm{Da}$. Results showed that $\beta$-lg was almost resistant to pepsin digestion and that the three plant hydrocolloids inhibited significantly $\beta$-lg digestibility as determined using dialysis bag with a 1000Da MW cutoff. Among the three polysaccharides used, xylan showed a digestibility decrease greater than that obtained with gum arabic and low-methylated pectin. On the other hand, no significant effect of polysaccharides on the in vitro $\beta$-lg digestibility was detected using the dialysis bag with an 8000 Da MW cutoff. This mainly suggests that peptides with MW in the range 1000 to $8000 \mathrm{Da}$ may interact with polysaccharides more than peptides and proteins with a greater molecular weight to decrease the protein digestibility, and that the nature of the polysaccharides plays a role in the interaction.
\end{abstract}

(Key words: $\beta$-lactoglobulin, gum arabic, protein-polysaccharide interaction, protein digestibility)

Received April 9, 2003.

Accepted July 1, 2003.

Corresponding author: J. Mouécoucou; e-mail: justinemouecoucou @yahoo.fr.

${ }^{1}$ Current address: Faculté de Médecine et des Sciences de la Santé, Université des Sciences de la Santé, Libreville, Gabon.
Abbreviation key: $\beta$-lg $=\beta$-lactoglobulin, $\mathbf{L M}=$ low methylated, $\mathbf{P D}=$ peptic digestibility, $\mathbf{p H i}=$ isoelectric point, $\mathbf{T P D}=$ total protein digestibility .

\section{INTRODUCTION}

$\beta$-Lactoglobulin $(\beta$-lg) represents $50 \%$ of whey protein in cow milk and does not exist in human milk. At physiological $\mathrm{pH}, \beta-\mathrm{lg}$ is a dimer with a molecular weight about $36,400 \mathrm{Da}$ (McKenzie, 1971) and an isoelectric $\mathrm{pH}$ (pHi) around 5.2. It contains four disulphide bonds per dimer and a free cystein residue. The disulphide bonds play a major role in the structural integrity of the protein (Mc Kenzie, 1971). Their reduction destabilizes the conformation of the $\beta$-lg. This structure explains the resistance of $\beta$-lg to digestive enzymes in the gastrointestinal tract. $\beta$-Lactoglobulin reaches the intestinal mucosa almost intact and can be absorbed, inducing allergenic reactions (Reddy et al., 1988; Mahé et al., 1996). The resistance of whey proteins to digestive enzymes was also demonstrated in vitro (Reddy et al., 1988; Schmidt and Poll, 1991). Cleavage of disulphide bonds by industrial treatments of milk such as sterilization, heating, or hydrostatic high pressure enhances the digestibility of whey proteins, especially $\beta$ lg (Reddy et al., 1988; Schmidt and Van Markwigh, 1993; Van Camp and Huyghebaert, 1995; Kananen et al., 2000).

An increasing number of dairy products such as yogurt drinks, flavored milk, flans, custards, cream, ice cream, and puddings contain plant soluble polysaccharides such as alginates, carrageenans, pectins, gum arabic, guar gum, or locust bean gum. Interactions between polysaccharides and milk proteins, depending on the aqueous environmental conditions $\mathrm{pH}$ and ionic strength), charge density of the two macromolecules 
and molecular weight of polysaccharides (Dickinson, 1998; Schmitt et al., 1998; Syrbe et al., 1998), improve the texture and stability of dairy products. When these two macromolecules are mixed together in water, phase separation generally occurs, leading either to the segragation of each macromolecule in separated phases (segregative phase separation) or the concentration of both macromolecules in one phase with the appearance of an equilibrium dilute phase (associative phase separation) (Albertsson, 1995; Schmitt et al., 1998). In this latter phase, the formation of protein-polysaccharide complexes is due to strong interactions (covalent bonding) or to several weak interactions (electrostatic, Van der Waals, hydrogen, or hydrophobic bonding).

The ability of proteins and polysaccharides to induce the formation of complexes could have consequences on the physiological fate of proteins. Low protein hydrolysis, decrease of hydrolyzed protein absorption, and decrease of animal growth are generally observed with addition of soluble polysaccharides to foods at low or high levels (Jenkins et al., 1978, Shah et al., 1982; Low and Rainbird, 1984; Schneeman and Gallaher, 1985; Mouécoucou et al., 1990, 1995; Astwood and Morris, 1992; Larsen et al., 1994; Eggum, 1995; Ellis et al., 1995; Hsu et al., 1996; Grala et al., 1999; El Kossori et al., 2000).

The main objective of this study was to determine the effects of gum arabic, low methylated pectin, and xylan on the in vitro digestibility of $\beta$-lg. Gum arabic, also called acacia gum, the natural exudate from the Acacia senegal, is a high molecular weight polysaccharide consisting of branched arabinogalactan heteropolymers (Anderson et al., 1983; Street and Anderson, 1983). Gum arabic also contains proteins (2\%) covalently attached to the polysaccharide moiety. Low methylated pectin, is a biopolymer essentially made up of $\mathrm{D}$ galacturonic residues. The presence of uronic acids is responsible for the polyanionic character of gum arabic and pectins, with a pHi around 3 (Kravtchenko, 1997; Wang and Qvist, 2000). They are both used in food industry. Xylan extracted from Palmaria palmata, a red seaweed authorized in human nutrition, is a linear oligomer composed of 1-3/1-4 linked xylose in proportion of $1 / 4$ and $1 / 3$, respectively, with a low molecular weight, and a mean degree of polymerization around 8 to 12 .

Hydrolysis was done using two models. In the first model, $\beta$-lg was hydrolyzed by pepsin, mimicking the in vivo gastric digestion, by reducing progressively the $\mathrm{pH}$ (Bernier et al., 1988). In the second model according to Savoie and Gauthier (1986), $\beta$-lg was hydrolyzed by a mixture of trypsin and chymotrypsin into a dialysis cell. Dialysis bags with two different MW cutoffs were used to estimate the $\beta$-lg digestibility. The aim of using two MW cutoffs was to assess the effects of polysaccharides on $\beta$-lg digestibility in the physiologic situation (bag with a MW cutoff of $1000 \mathrm{Da}$ ), and in nonphysiological, when high MW peptides diffused through the intestinal barrier as in the case of some allergenic proteins (bag with a MW cutoff of $8000 \mathrm{Da}$ ).

\section{MATERIALS AND METHODS}

\section{Materials}

Acid-processed bovine $\beta$-lg powder (lot no. 838) was kindly provided by Lactalis (Retiers, France). Its composition was $(\mathrm{g} / 100 \mathrm{~g}): 89.75 \%$ protein $(\mathrm{N} \times 6.38)$. Powdered gum arabic (lot no. $97 \mathrm{~J} \mathrm{716)}$ was a gift from the Colloïdes Naturels International Company (CNI, Rouen, France). It contained $89.95 \%$ polysaccharide. Xylan (lot no. PP28-4-00) was extracted from a Rodophyceae, Palmaria palmata or dulse by the Laboratoire de Pathologie Cellulaire et Moléculaire en Nutrition (Faculté de Médecine Vandoeuvre-lès-Nancy, France). It contained $80.40 \%$ pentose, $13.20 \%$ hexose. Low methylated (LM) pectin (lot no. 0B800), with $87 \%$ polysaccharide, was provided by Degussa Texturant Systems (Boulogne-Billancourt, France).

Pepsin (3800 U/mg protein, 1:60,000, EC 3.4.23.1), bovine trypsin (13,800 U/mg, EC 3.4.21.4), porcine chymotrypsin (51 U/mg, EC 3.4.4.5), and thimerosal were purchased from Sigma (France).

Sodium hydroxide, hydrochloride, and trichloroacetic acid were of analytical grade.

\section{Methods}

Preparation of $\beta$-lg/polysaccharide mixtures. $\beta$ Lactoglobulin/polysaccharide mixtures were measured in percent by weight (\%wt). $\beta$-Lactoglobulin powder containing $40 \mathrm{mg}$ of $\mathrm{N}(1.7 \%$ wt of protein, $\mathrm{N} \times 6.38)$ was taken in triplicate and dissolved in $15 \mathrm{ml}$ of sodium phosphate buffer $0.17 \mathrm{M} \mathrm{pH} 7$ under gentle mixing. Polysaccharides were dissolved in the same buffer at the same concentration (1.7\% wt). Dispersions were left overnight at $4^{\circ} \mathrm{C}$ to allow complete hydration of macromolecules. The $\beta$-lg and polysaccharide stock were blended so as to obtain 0 ( $\beta$-lg without polysaccharide), $1,10,20,30$, and $50 \%$ weight of relative polysaccharide concentration (as compared to the $\beta$-lg concentration). Thimerosal was added to $\beta-\mathrm{lg} /$ polysaccharide mixtures at $50 \mathrm{mg} / \mathrm{L}$ to avoid bacterial growth.

Enzymatic digestions. Two different models of enzymatic digestions of $\beta-\mathrm{lg} /$ polysaccharide mixtures were performed:

1) A peptic digestion, with an acidification kinetics mimicking the in vivo gastric digestion (Bernier, 
1988), stopped at different $\mathrm{pH}$ values $(5,4,3$, and 2 ) by adding trichloroacetic acid (TCA). A nitrogen analysis was then performed to determine the degree of hydrolysis.

2) A total proteic digestion carried out in a system involving a two step-hydrolysis. In the first step, a peptic digestion was made and in a second step, trypsin and chymotrypsin digestion was made in dialysis bags with two different molecular weight cutoffs (1000 and $8000 \mathrm{Da})$. Nitrogen in dialysates was determined.

Peptic digestion. One millilliter of pepsin in $0.02 \mathrm{~N}$ $\mathrm{HCl}(1 \mathrm{mg} / \mathrm{ml})$ was added to $15 \mathrm{ml}$ of $\beta-\mathrm{lg} /$ polysaccharide mixtures (E/S: 1/250). For simulating the in vivo gastric digestion, the $\mathrm{pH}$ of dispersions was progressively reduced from $\mathrm{pH} 7$ to 2 within $2 \mathrm{~h}$ by adding $\mathrm{HCl} 0.02 \mathrm{~N}$ with a peristaltic pump (flow rate: $80 \mu \mathrm{l} / \mathrm{min}$ ) at $37^{\circ} \mathrm{C}$. The digestion was stopped at $\mathrm{pH} 5,4,3$, and 2 by adding $30 \%$ (vol/vol) TCA. Samples were centrifuged at 5000 rpm for 20 min (Beckman Coulter; Villepinte, France). Pellets were discarded and $10 \mathrm{ml}$ of supernatant were taken for soluble $\mathrm{N}$ analysis. Experiments were made in triplicate and assays in duplicate.

Total proteic digestion. The in vitro total digestion of $\beta-\mathrm{lg} /$ polysaccharide mixtures was carried out at $37^{\circ} \mathrm{C}$ in a dialysis cell (Serna, Laval, Quebec) according to the two-step hydrolysis method developed by Savoie and Gauthier (1986), with minor modifications of the first step. The dialysis cell consisted of an inner compartment (a dialysis bag), where digestion occurs, fixed into a double-wall cylindrical outer compartment with buffer circulation.

In the first step, peptic digestion of $\beta$-lg/polysaccharide mixtures was made as described in the previous section. Peptic digestion was stopped by raising the $\mathrm{pH}$ to 8 with $\mathrm{NaOH} 2 \mathrm{~N}$. In the second step, the samples previously submitted to peptic digestion were transferred to dialysis bags with MW cutoff of 1000 or 8000 $\mathrm{Da}$ (SpectraPor 6, Interchim, Montluçon, France). Then, $1 \mathrm{ml}$ of a mixture of trypsin/chymotrypsin (1/2.3, $\mathrm{wt} / \mathrm{wt}$ ) at a weight concentration of $2.5 \mathrm{mg} / \mathrm{ml}$ (enzyme/ substrate 1/50) was added. Digestion products diffusing through the dialysis bag were collected every hour during $6 \mathrm{~h}$ by a circulating $(1.6 \mathrm{ml} / \mathrm{min})$ sodium phosphate buffer $0.01 M \mathrm{pH} \mathrm{8}$, and the fractions were taken for the $\mathrm{N}$ analysis. Experiments were made in triplicate and assays in duplicate.

\section{Nitrogen Analysis}

The total $\mathrm{N}$ content in supernatants (peptic digestion) or dialysates (total proteic digestion) was determined by the micro Kjeldhal procedure, according to AOAC methods (47.021 and 47.023). The protein digestibility was calculated as follows:

Protein digestibility $(\%)=\mathrm{N}$ in supernatants or dialysates $(\mathrm{mg}) \times 100 / \mathrm{N}$ in protein sample $(\mathrm{mg})$.

\section{Statistical Analysis}

The results are given as mean \pm standard deviation of samples and were analyzed by a one-way analysis of variance (ANOVA, Statview V). Differences between means at $P<0.05$ were analyzed using the Fisher test.

\section{RESULTS}

Peptic digestion. The effect of plant hydrocolloids on the in vitro $\beta$-lg peptic digestibility (PD) is showed in Table 1 . The digestibility of $\beta$-lg alone was very low at all $\mathrm{pH}$ considered with $\mathrm{PD}$ values comprised between 1 and $2 \%$.

The presence of gum arabic (Table 1A), LM pectin (Table 1B) and xylan (Table 1C) at levels 1 and $10 \% \mathrm{wt}$ did not change significantly the $\beta$-lg peptic digestibility. As a general trend, high levels of polysaccharides $(50 \%$ wt for gum arabic and LM pectin; 30 and 50\% wt for xylan) resulted in a low but significant increase of $\beta-\mathrm{lg}$ peptic digestibility at all $\mathrm{pH}$ values compared with the protein alone.

Total proteic digestion (dialysis membrane with cutoff of $1000 \mathrm{Da}$ ). After $6 \mathrm{~h}$ of hydrolysis with a mixture of trypsin and chymotrypsin at $\mathrm{pH} 8$, the total proteic digestibility (TPD) in the control $\beta$-lg was $27.5 \%$ \pm 3.5 (Figure 1). This value was significantly lower in presence of gum arabic, LM pectin, or xylan.

All polysaccharides, from the $\mathrm{h} 1$ until 6 of digestion, decreased significantly $\beta$-lg digestibility when they were present at levels higher than $1 \%$ wt $(P<0.001)$. After $6 \mathrm{~h}$ of hydrolysis, the highest decreasing effect was obtained with $50 \%$ wt of polysaccharides. Xylan (Figure 1C) decreased significantly more $\beta$-lg digestibility than both gum arabic (Figure 1A) and LM pectin (Figure 1B). There was no significant difference between the ability of LM pectin and gum arabic to decrease digestibility.

Total proteic digestion (dialysis membrane with a MW cutoff of $8000 \mathrm{Da}$ ). Proteolysis in a dialysis bag with a MW cutoff of 8000 Da was made under the same experimental conditions as in the dialysis bag with a MW cutoff of $1000 \mathrm{Da}$ (Figure 2). No differences in the calculated TPD were observed. The TPD in the control $\beta$-lg after $6 \mathrm{~h}$ of digestion was $32.05 \% \pm 5.95$. The presence of the three polysaccharides did not significantly modify this TPD value during the time of hydrolysis, 
Table 1. Influence of different levels of plant polysaccharides on the peptic digestibility of $\beta$-lg $(\%)$.

\begin{tabular}{|c|c|c|c|c|c|c|}
\hline \multicolumn{7}{|c|}{ A } \\
\hline \multicolumn{7}{|c|}{ Levels of gum arabic (\%wt) } \\
\hline $\mathrm{pH}$ & 0 & 1 & 10 & 20 & 30 & 50 \\
\hline 5 & $1.3 \pm 0.15^{\mathrm{a}, \mathrm{A}}$ & $1.13 \pm 0.08^{\mathrm{a}, \mathrm{A}}$ & $1.08 \pm 0.13^{\mathrm{a}, \mathrm{A}}$ & $1.32 \pm 0.76^{\mathrm{a}, \mathrm{A}}$ & $1.76 \pm 0.08^{\mathrm{b}, \mathrm{A}}$ & $4.06 \pm 0.38^{\mathrm{c}, \mathrm{A}}$ \\
\hline 4 & $1.32 \pm 0.04^{\mathrm{a}, \mathrm{A}}$ & $0.99 \pm 0.04^{\mathrm{b}, \mathrm{A}}$ & $1.21 \pm 0.07^{\mathrm{a}, \mathrm{A}}$ & $1.40 \pm 0.03^{\mathrm{a}, \mathrm{B}}$ & $1.51 \pm 0.19^{\mathrm{a}, \mathrm{A}}$ & $2.5 \pm 0.18^{\mathrm{b}, \mathrm{B}}$ \\
\hline 3 & $1.61 \pm 0.04^{\mathrm{a}, \mathrm{B}}$ & $1.55 \pm 0.01^{\mathrm{a}, \mathrm{B}}$ & $1.31 \pm 0.12^{\mathrm{b}, \mathrm{A}}$ & $1.50 \pm 0.12^{\mathrm{a}, \mathrm{A}}$ & $1.89 \pm 0.05^{\mathrm{c}, \mathrm{B}}$ & $3.10 \pm 0.13^{\mathrm{d}, \mathrm{C}}$ \\
\hline 2 & $2.07 \pm 0.14^{\mathrm{a}, \mathrm{C}}$ & $2.01 \pm 0.14^{\mathrm{a}, \mathrm{C}}$ & $1.9 \pm 0.19^{\mathrm{a}, \mathrm{B}}$ & $1.85 \pm 0.07^{\mathrm{a}, \mathrm{B}}$ & $2,67 \pm 0.04^{\mathrm{b}, \mathrm{C}}$ & $3.92 \pm 0.14^{\mathrm{c}, \mathrm{A}}$ \\
\hline
\end{tabular}

B

\begin{tabular}{lrllllll}
\hline & \multicolumn{7}{c}{ Levels of LM pectin (\%wt) } \\
\cline { 2 - 8 } $\mathrm{pH}$ & \multicolumn{1}{c}{0} & 1 & 10 & 20 & 30 & 50 \\
\hline 5 & $1.3 \pm 0.15^{\mathrm{a}, \mathrm{A}}$ & $0.98 \pm 0.09^{\mathrm{b}, \mathrm{A}}$ & $1.05 \pm 0.01^{\mathrm{b}, \mathrm{A}}$ & $1.91 \pm 0.08^{\mathrm{c}, \mathrm{A}}$ & $2.43 \pm 0.02^{\mathrm{d}, \mathrm{A}}$ & $2.24 \pm 0.02^{\mathrm{e}, \mathrm{A}}$ \\
4 & $1.32 \pm 0.04^{\mathrm{a}, \mathrm{A}}$ & $1.00 \pm 0.05^{\mathrm{b}, \mathrm{A}}$ & $1.23 \pm 0.06^{\mathrm{a}, \mathrm{B}}$ & $0.78 \pm 0.01^{\mathrm{c}, \mathrm{B}}$ & $0.83 \pm 0.02^{\mathrm{c}, \mathrm{B}}$ & $2.42 \pm 0.02^{\mathrm{d}, \mathrm{B}}$ \\
3 & $1.61 \pm 0.04^{\mathrm{a}, \mathrm{B}}$ & $1.28 \pm 0.05^{\mathrm{b}, \mathrm{B}}$ & $1.12 \pm 0.01^{\mathrm{c}, \mathrm{B}}$ & $1.19 \pm 0.09^{\mathrm{bc}, \mathrm{C}}$ & $1.48 \pm 0.04^{\mathrm{a}, \mathrm{C}}$ & $3.58 \pm 0.03^{\mathrm{d}, \mathrm{C}}$ \\
2 & $2.07 \pm 0.14^{\mathrm{a}, \mathrm{C}}$ & $1.36 \pm 0.02^{\mathrm{b}, \mathrm{B}}$ & $1.31 \pm 0.01^{\mathrm{b}, \mathrm{B}}$ & $1.15 \pm 0.02^{\mathrm{c}, \mathrm{C}}$ & $1.85 \pm 0.05^{\mathrm{a}, \mathrm{D}}$ & $4.44 \pm 0.09^{\mathrm{d}, \mathrm{D}}$ \\
\hline
\end{tabular}

C

\begin{tabular}{|c|c|c|c|c|c|c|}
\hline \multirow[b]{2}{*}{$\mathrm{pH}$} & \multicolumn{6}{|c|}{ Levels of xylan (\%wt) } \\
\hline & 0 & 1 & 10 & 20 & 30 & 50 \\
\hline 5 & $1.3 \pm 0.15^{\mathrm{a}, \mathrm{A}}$ & $1.26 \pm 0.02^{\mathrm{a}, \mathrm{A}}$ & $1.31 \pm 0.09^{\mathrm{a}, \mathrm{A}}$ & $1.84 \pm 0.05^{\mathrm{b}, \mathrm{A}}$ & $1.74 \pm 0.05^{\mathrm{b}, \mathrm{A}}$ & $1.74 \pm 0.03^{\mathrm{b}, \mathrm{A}}$ \\
\hline 4 & $1.32 \pm 0.04^{\mathrm{a}, \mathrm{A}}$ & $1.23 \pm 0.02^{\mathrm{a}, \mathrm{A}}$ & $1.27 \pm 0.04^{\mathrm{a}, \mathrm{A}}$ & $1.59 \pm 0.06^{\mathrm{b}, \mathrm{B}}$ & $1.87 \pm 0.06^{\mathrm{c}, \mathrm{A}}$ & $2.82 \pm 0.02^{\mathrm{d}, \mathrm{B}}$ \\
\hline 3 & $1.61 \pm 0.04^{\mathrm{a}, \mathrm{B}}$ & $1.41 \pm 0.01^{\mathrm{b}, \mathrm{B}}$ & $1.34 \pm 0.03^{\mathrm{c}, \mathrm{A}}$ & $1.49 \pm 0.03^{\mathrm{b}, \mathrm{B}}$ & $1.68 \pm 0.03^{\mathrm{d}, \mathrm{A}}$ & $2.54 \pm 0.02^{\mathrm{e}, \mathrm{C}}$ \\
\hline 2 & $2.07 \pm 0.14^{\mathrm{a}, \mathrm{C}}$ & $2.12 \pm 0.01^{\mathrm{a}, \mathrm{C}}$ & $2.14 \pm 0.02^{\mathrm{a}, \mathrm{B}}$ & $2.00 \pm 0.02^{\mathrm{a}, \mathrm{C}}$ & $2.48 \pm 0.02^{\mathrm{b}, \mathrm{B}}$ & $3.32 \pm 0.11^{\mathrm{c}, \mathrm{D}}$ \\
\hline
\end{tabular}

whatever the level of polysaccharides in the $\beta$-lg dispersions.

\section{DISCUSSION}

The effect of gum arabic, LM pectin, and xylan on the in vitro digestibility of $\beta$-lg was estimated using gastric peptic and peptic followed by trypsic/chymotrypsic digestion models.

In the peptic model, the $\mathrm{pH}$ was progressively reduced from 7 to 2 within $2 \mathrm{~h}$ as is generally observed in vivo. The products of peptic digestion are high molecular weight peptides, which mainly precipitate with TCA, leading to small amounts of soluble $\mathrm{N}$. The digestibility of $\beta$-lg by pepsin was very low at $\mathrm{pH} 2$, where $\beta$ $\mathrm{lg}$ is in a monomeric form (Mc Kenzie, 1971). Reddy et al. (1988) and Schmidt and Poll (1991) have already reported a low in vitro $\beta$-lg hydrolysis by pepsin using different methods. Our results also agree with in vivo studies demonstrating the presence of intact $\beta$-lg after its passage through the stomach (Miranda and Pelissier, 1983; Yvon et al., 1984). Kella and Kinsella (1988) suggested that the acid stability of $\beta$-lg could result from increased internal $\mathrm{H}$ bonding arising from either two titrated carboxyl groups or from one amide and one carboxyl group. The increase in PD observed with 30 and $50 \%$ wt of polysaccharides is not due to an increased ability of pepsin to hydrolyze $\beta$-lg, but is due rather to an incomplete TCA precipitation of protein resulting of protein/polysaccharide interactions. Electrostatic interactions between $\beta$-lg and polysaccharides likely occur in the $\mathrm{pH}$ range 3 to 5 , where the two macromolecules carry opposite charge. The formation of protein/ polysaccharide macromolecular complexes or aggregates of complexes could decrease the protein precipitation by TCA, resulting in the erroneous conclusion of a stronger $\beta$-lg proteolysis. This hypothesis is reinforced by the observation that the effect is stronger in mixtures containing the higher polysaccharide concentrations.

The $\beta$-lg digestibility calculated after hydrolysis of peptic and pancreatic enzymes hydrolysis in a dialysis bag with a MW cutoff of 1000 Da was about $27 \%$. The main role of pepsin is to hydrolyze bonds between aromatic amino acids (tyrosine and phenylalanine) and to facilitate the digestion by pancreatic enzymes (Savoie and Gauthier, 1986; Reddy et al., 1988; Mullaly et al., 1998). Some authors have shown that pepsin makes 
A

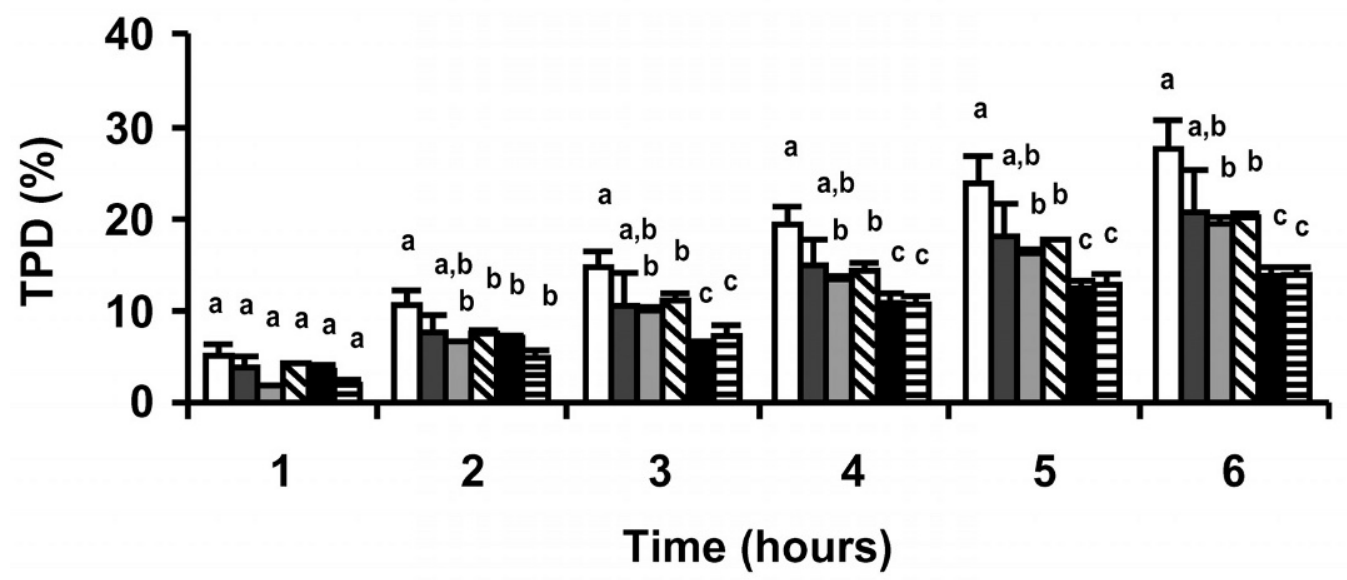

B
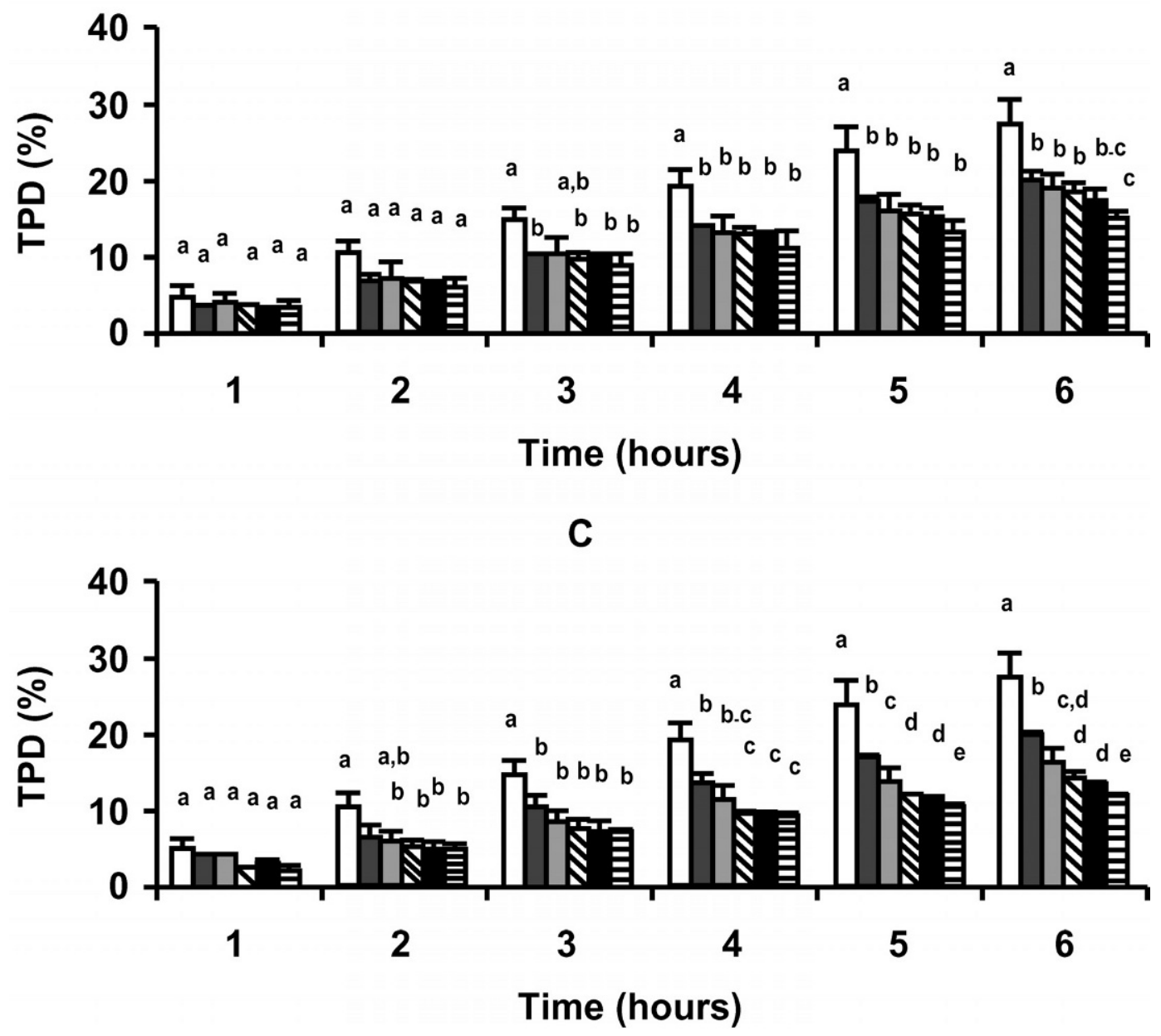

Figure 1. Influence of different levels of plant polysaccharides on the total protein digestibility (TPD) of $\beta$-lactoglobulin ( $\beta$-lg) (membrane with a MW cutoff of $1000 \mathrm{Da}$ ). A (gum arabic); B (LM pectin), C (xylan). $\beta$-lg (white), $\beta$-lg $+1 \%$ wt polysaccharides (dark gray), $\beta$-lg $+10 \%$ wt polysaccharides (light gray), $\beta$-lg $+20 \%$ wt polysaccharides (diagonal), $\beta$-lg $+30 \%$ wt polysaccharides (black), and $\beta$-lg $+50 \%$ wt polysaccharides (horizontal). Data are means $\pm \mathrm{SD}(\mathrm{n}=6)$. Values with different letters are significantly different at $P<0.05$. 

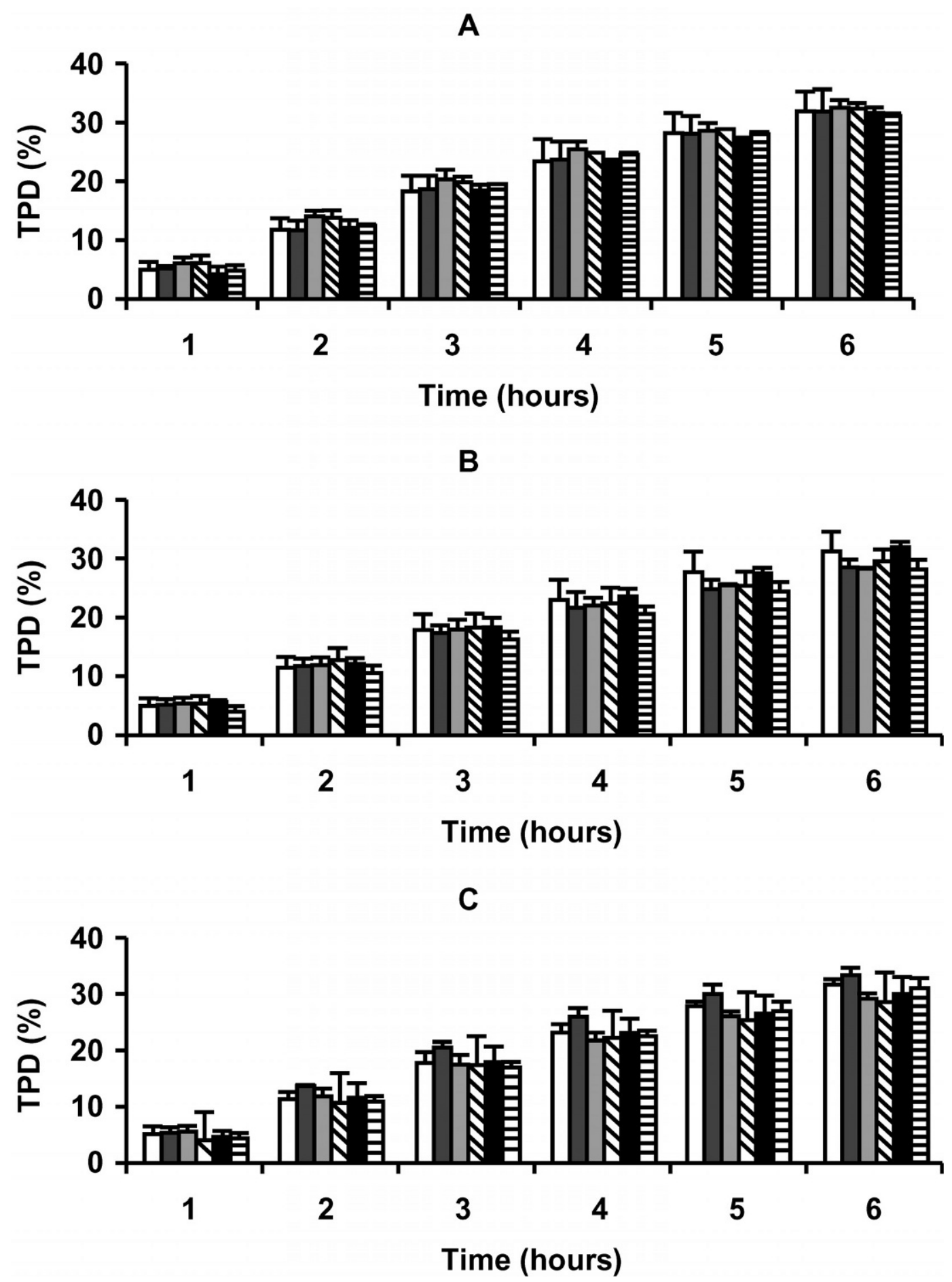

Figure 2. Influence of different levels of plant polysaccharides on the total protein digestibility (TPD) of $\beta$-lg (membrane with a MW cutoff of $8000 \mathrm{Da}$ ). A (gum arabic); $\mathrm{B}$ (LM pectin), $\mathrm{C}$ (xylan). $\beta$-lg (white), $\beta$-lg $+1 \%$ wt polysaccharides (dark gray), $\beta$-lg $+10 \%$ wt polysaccharides (light gray), $\beta$-lg $+20 \%$ wt polysaccharides (diagonal), $\beta$-lg $+30 \%$ wt polysaccharides (black), and $\beta$-lg $+50 \%$ wt polysaccharides (horizontal) Data are means $\pm \mathrm{SD}(\mathrm{n}=6)$. No significant difference was obtained at $P<0.05$. 
the molecular structure of $\beta$-lg more susceptible to proteolytic attack by other proteinases (Porter et al., 1984; Antila et al., 1991). Trypsin and chymotrypsin cleave bonds between basic amino acids (lysine and arginine) and aromatic amino acids (tryptophan, phenylalanine, tyrosine), respectively. At $\mathrm{pH} 8, \beta$-lg undergoes a conformational change (Tanford transition) and is in a monomeric form, which makes the access of enzymes to a few strategic peptide bonds easier (Kella and Kinsella; 1988; Reddy et al., 1988; Chobert et al., 1991).

The addition of gum arabic, LM pectin, or xylan decreased the digestibility of $\beta$-lg and the decrease was dependent on the level and the type of polysaccharide. Among the three polysaccharides used, xylan produced the most remarkable effect. Scince three polysaccharides have different chemical structures and different physico-chemical properties, their aptitudes to alter $\beta$ lg digestibility are also different. One possible hypothesis to explain the decrease of $\beta$-lg digestibility is the ability of most polysaccharides to increase the apparent viscosity of mixtures. Increasing the apparent viscosity of protein/polysaccharide mixtures is usually related to low protein digestibility and low nutrient absorption (Schneeman and Gallaher, 1985; Edwards et al. 1988; Häglund et al. 1988). Gum arabic (Sanchez et al., 2002) and xylan (data not shown) dispersions displayed low apparent viscosities at low polysaccharide concentrations, as was the case in our experiment. So, in these cases the apparent viscosity cannot explain the reduction of trypsin/chymotrypsin protein digestibility.

Another possible hypothesis is the existence of nonspecific interactions between molecular species in protein/polysaccharides mixture. The three polysaccharides and $\beta$-lg have negative charges at $\mathrm{pH} 8$, and electrostatic interactions between biopolymers are therefore unlikely. Nevertheless, weak local electrostatic interactions can occur at neutral $\mathrm{pH}$ between anionic polysaccharides and positively charged regions called "patches" on protein molecules (Imeson et al., 1977; Tolstoguzov, 1986; Xia and Dubin, 1994). Native $\beta$-lg and anionic polysaccharides (dextran sulfate and propylene glycol alginate) have already been shown to form ionic complexes at neutral pH (Dickinson and Galazka, 1991). Possible electrostatic interactions between $\beta$-lg and gum arabic have been suggested recently at $\mathrm{pH} 5.3$, but no evidence of interactions at $\mathrm{pH}$ $>$ pHi has been provided (Weinbreck et al., 2003). It is then doubtful that electrostatic interactions between $\beta$ $\mathrm{lg}$ and polysaccharides could occur at $\mathrm{pH} 8$. Nonionic interactions such as hydrogen bonding can also lead to the formation of protein-polysaccharide complexes (Imeson et al., 1977; Antonov and Soshinsky, 2000), then this possibility cannot be totally excluded. Another possibility is that electrostatic interactions occurred be- tween polysaccharides and positively charged peptides, containing for instance arginine and lysine, released by trypsin hydrolysis (Knudsen et al., 2002).

No significant effect of polysaccharides on the in vitro $\beta$-lg digestibility was detected using the dialysis bag with a MW cutoff of $8000 \mathrm{Da}$, suggesting that the difference between the total protein digestibility with both membranes could be explained in part by polysaccharide-peptide interactions. Furthermore, since the protein digestibility determined using the dialysis bag with a MW cutoff of $1000 \mathrm{Da}$ was close to that obtained with the second dialysis bag, it seems that $\beta$-lg was more readily cleaved into small peptides without polysaccharides and into larger peptides in mixtures containing polysaccharides. Several workers have demonstrated the formation of peptides upper $2000 \mathrm{Da}$ after trypsin, chymotrypsin, bromelain, or papain $\beta$-lg hydrolysis (Chobert et al., 1991; Schmidt and Poll, 1991; Turgeon et al., 1992; Schmidt and Van Markwigh, 1993; Madsen et al., 1998; Otte et al., 1998, Pintado et al., 1999) to a lesser extent in the range of 1000 to $1500 \mathrm{Da}$. Determination of the size distribution of released peptides during $\beta$-lg hydrolysis is needed to verify the hypothesis. Our results suggest that polysaccharides inhibit only the cleavage of peptides under $1000 \mathrm{Da}$ coming from $\beta$ $\lg$ but not the cleavage of peptides upwards of 8000 Da. Peptides in dialysates had to be characterized for explain results observed with two different membranes.

\section{CONCLUSIONS}

Different responses in peptic and trypsic/chymotrypsic $\beta$-lg digestibility with the three polysaccharides where shown using two models of digestion. Decrease of $\beta$-lg digestibility by plant hydrocolloids when hydrolysis occurred into the dialysis bag with a MW cutoff of 1000 Da was observed. This was not observed with the dialysis bag with a MW cutoff of $8000 \mathrm{Da}$. Continuation of this work requires studying the mechanisms that could explain the effects of polysaccharides on $\beta$-lg digestibility. Characterizing the peptides in dialysates from each dialysis bag could lead to a better understanding of the phenomena observed.

\section{REFERENCES}

Albertsson, P. A. 1995. Aqueous polymer phase systems: properties and applications in bioseparation. Pages 1-12 in Biopolymer Mixtures. S.E. Harding, S. E. Hill, and J. R. Mitchell, eds. Nottingham University Press, Nottingham, UK.

Anderson, D. M. W., M. M. E. Bridgeman, J. G. K. Farquhar, and C. G. A. McNab. 1983. The chemical characterization of the test article in toxicological studies of gum arabic (Acacia Senegal (L.) Willd). Int. Tree Crops J. 2:245-254.

Antila, P., I. Paakkari, A. Järvinen, M. J. Mattila, M. Laukkanen, Ä. Pihlanto-Leppälä, P. Mäntsälä, and J. Hellman. 1991. Opioid 
peptides derived from "in vitro" proteolysis of bovine whey proteins. Int. Dairy J. 1:215-229.

Antonov, Y. A., and A. A. Soshinsky. 2000. Interactions and compatibility of ribuloso-1,5-bisphosphate carboxylase/oxygenase from alfalfa with pectin in aqueous medium. Int. J. Biol. Macromol. 27:279-285.

Astwood, M. A., and E. R. Morris. 1992. Physical properties of dietary fiber that influence physiological function: a model for polymers along the gastrointestinal tract. Am. J. Clin. Nutr. 55:436-442.

Bernier, J. J., J. Adrian, and N. Vidon. 1988. Les aliments dans le tube digestif, Doin, Paris.

Chobert J. M., M. Dalgalarrondo, E. Dufour, C. Bertrand-Harb, and T. Haertle. 1991. Influence of $\mathrm{pH}$ on the structural changes of $\beta$ lactoglobulin studied by trypsin hydrolysis. Biochim. Biophys. Acta 1077:31-34.

Dickinson, E., and V. B. Galazka. 1991. Emulsion stabilization by ionic and covalent complexes of $\beta$-lactoglobulin with polysaccharides. Food Hydrocoll. 5:281-296.

Dickinson, E. 1998. Stability and rheological implications of electrostatic milk protein-polysaccharide interactions. Trends Food Sci. Tech. 9:347-354.

Edwards, C. A., I. T. Johnson, and N. W. Read. 1988. Do viscous polysaccharides reduce absorption by inhibiting diffusion or convection? J. Am. Clin. Nutr. 42:307-312.

Eggum, B. O. 1995. The influence of dietary fibre on protein digestion and utilization in monogastrics. Arch. Anim. Nutr. 48:89-95.

El Kossori, R. L., C. Sanchez, E. S. El Boustani, M. N. Maucourt, Y. Sauvaire, L. Méjean, and C. Villaume. 2000. Comparison of effects of prickly pear (Opuntia ficus indica $s p$ ) fruit, arabic gum, carrageenan, alginic acid, locust bean gum and citrus pectin on viscosity and in vitro digestibility of casein. J. Sci. Food Agric. 80:359-364.

Ellis, P. R., F. G., Roberts, A. G. Low, and L. M. Morgan. 1995. The effect of high-molecular-weight guar gum on net apparent glucose absorption and net apparent insulin and gastric inhibitory peptide production in the growing pig: Relationship to rheological changes in jejunal digesta. Br. J. Nutr. 74:539-556.

Grala, W., M. W. A. Verstegen, A. J. M. Jansman, J. Huisman, and P. Van Leeuwen. 1999. Apparent digestibility and recovery of endogenous nitrogen at the terminal ileum of pigs fed diets containing various soyabean products, peas or rapeseeds hulls. Anim. Feed Sci. Technol. 80:231-245.

Haglund, B. O., M. Elisson, and L. O. Sundelöf. 1988. Diffusion permeability in concentrated polymer solutions. Chem. Scrip. 28:129131.

Hsu, J. C., T. W. Lu, P. W. S. Chiou, and B. Yu. 1996. Effects of different sources of dietary fibre on growth performance and apparent digestibility in geese. Anim. Feed Sci. Tech. 60:93-102.

Imeson, A. P., D. A. Ledward, and J. R. Mitchell. 1977. On the nature of the interaction between some polysaccharides and proteins. J. Sci. Food Agric. 28:661-668.

Jenkins, D. J. A., T. M. S. Wolever, and A. R. Leeds. 1978. Dietary fibers, fiber analogues and glucose tolerance: importance of viscosity. Br. Med. J. 1:1392-1394.

Kananen, A., J. Savolainen, J. Makinen, U. Perttilä, L. Myllykoski, and A. Pihlinto-Leppälä 2000. Influence of chemical modification of whey protein conformation on hydrolysis with pepsin and trypsin. Int. Dairy J. 10:691-697.

Kella, N. K. D., and J. E. Kinsella. 1988. Enhanced thermodynamic stability of $\beta$-lactoglobulin at low pH. Biochem. J. 255:113-118.

Knudsen, J. C., J. Otte, K. Olsen, and L. H. Skibsted. 2002. Effect of high hydrostatic pressure on the conformation of $\beta$-lactoglobulin A assessed by proteolytic peptide profiling. Int. Dairy J. 12:791-803.

Kravtchenko, T. P. 1997. Application of acacia gum as a natural source of soluble dietary fibre. Pages 56-60 in Food Ingredient Europe, Conference Proceedings. Miller Freeman, Maaersen, The Netherlands.

Larsen, F. M., M. N. Wilson, and P. J. Moughan. 1994. Dietary fiber viscosity and amino acid digestibility, proteolytic digestive enzyme activity and digestive organ weights in growing rats. J. Nutr. 124:833-841.
Low, A. G., and A. L. Rainbird. 1984. Effect of guar gum on nitrogen secretion into isolated loops of jejunum in conscious growing pigs. Br. J. Nutr. 52:499-505.

Madsen, J. S., T. O. Ahmt, J. Otte, T. Halkier, and K. B. Qvist. 1998. Hydrolysis of $\beta$-lactoglobulin with four different proteases monitered by capillary electrophoresis and high performance liquid chromatography. Int. Dairy J. 7:399-409.

Mahé, S., N. Roos, R. Benamouzig, L. Davin, C. Luengo, L. Gagnon, N. Gausserges, J. Rautureau, and D. Tomé. 1996. Gastrojejunal kinetics and the digestion of ${ }^{15} \mathrm{~N} \beta$-lactoglobulin and casein in human: The influence of the nature and quantity of the protein. Am. J. Clin. Nutr. 63:546-552.

McKenzie, H. A. 1971. $\beta$-Lactoglobulin. Page 257 in Milk Proteins. Vol. 2. H. A. Mc Kenzie, ed. Academic, New York, NY.

Miranda, G., and J. P. Pelissier. 1983. Kinetic studies of in vitro digestion of bovine unheated skim-milk protein in rat stomach. J. Dairy Res. 50:27-36.

Mouécoucou, J., C. Villaume, H. M. Bau, J. P. Nicolas, and L. Méjean. 1990. Effets des alginates et des carraghénates de sodium associés aux protéines de soja sur le coefficient d'efficacité protéique (CEP). Rep. Nutr. Dev. 30:541-547.

Mouécoucou, J., C. Villaume, H. M. Bau, A. Schwertz, J. P. Nicolas, and L. Méjean. 1995. Decreases of in vitro hydrolysis of soybean protein by sodium carrageenan. Pages 356-359 in Food Macromolecules and Colloids. E. Dickinson and D. Lorient, ed. Royal Society of Chemistry, London, UK.

Mullaly, M. M., R. Mehra, and R. J. Fitzgerald 1998. Thermal effects on the conformation and susceptibility of $\beta$-lactoglobulin to hydrolysis by gastric and pancreatic endopeptidases. Irish J. Agric. Food Res. 37:51-60.

Otte, J., M. Zakora, K. B. Qvist, C. E. Olsen, and T. V. Barkholt. 1998. Hydrolysis of bovine $\beta$-lactoglobulin by various proteases and identification of selected peptides. Int. Dairy J. 7:835-848.

Pintado, M. E., A. E. Pintado, and F. X. Malcata.1999. Controlled whey protein hydrolysis using two alternative proteases. J. Food Eng. 42:1-13.

Porter, D., H. E. Swaisgood, and G. L. Catignani. 1984. Characterization of an immobilized digestive enzyme system for determination of protein digestibility. J. Agric. Food Chem. 32:334-339.

Reddy, M., N. K. D. Kella, and J. E. Kinsella. 1988. Structural and conformational basis of the resistance of $\beta$-lactoglobulin to peptic and chymotryptic digestion. J. Agric. Food Chem. 36:737-741.

Sanchez, C., D. Renard, P. Robert, C. Schmitt, and J. Lefebvre. 2002. Structure and rheological properties of acacia gum dispersions. Food Hydrocoll. 16:257-267.

Savoie, L., and R. Gauthier. 1986. Dialysis cell for the in vitro measurement of protein digestibility. J. Food Sci. 51:494-498.

Schmidt, D. G., and J. K. Poll. 1991. Enzymatic hydrolysis of whey proteins. Hydrolysis of $\alpha$-lactalbumin and $\beta$-lactoglobulin in buffer solutions by proteolytic enzymes. Neth. Milk Dairy J. 45:225-240.

Schmidt, D. G., and B. W. Van Markwigh. 1993. Enzymatic hydrolysis of whey proteins. Influence of heat treatment of $\alpha$-lactalbumin and $\beta$-lactoglobulin on their proteolysis by pepsin and papain. Neth. Milk Dairy J. 47:15-22.

Schmitt, C., C. Sanchez, S. Deshobry-Banon, and J. Hardy. 1998. Structure and technofunctional properties of protein-polysaccharides complexes: a review. Crit. Rev. Food Sci. Nutr. 38:689-753.

Schneeman, B. O., and D. Gallaher.1985. Effect of dietary fiber on digestive enzyme activity and bile acid in the small intestine. Proc. Soc. Exp. Biol. Med. 180:409-414.

Shah, N., M. T. Atallah, R. R. Mahoney, and P. Pellet. 1982. Effect of dietary fiber components on fecal nitrogen excretion and protein utilization in growing rats. J. Nutr. 112:658-666.

Street C. A., and D. M. W. M. Anderson. 1983. Refinement of the structures previously proposed for gum arabic and other Acacia gum exudates. Talanta 30:887-893.

Syrbe, A., W. J. Bauer, and H. Klostermeyer. 1998. Polymer science concepts in dairy systems. An overview of milk protein and food hydrocolloid interaction. Int. Dairy J. 8:179-193.

Tolstoguzov, V. B. 1986. Functional properties of protein-polysaccharide mixture. Pages 385-415 in Functional properties of food 
macromolecules. J. R. Mitchell and D. A Ledward, ed. Elsevier, London, UK.

Turgeon, S. L., S. F. Gauthier, D. Molled, and J. Leonil.1992. Interfacial properties of tryptic peptides of $\beta$-lactoglobulin. J. Agric. Food Chem. 40:669-675.

Van Camp, J., and A. Huyghebaert. 1995. High pressure-induced gel formation of whey protein and haemoglobin protein concentrated. Lebensm-Wiss. Technol. 28:111-117.

Yvon, M., I. Van Hille, J. P. Pelissier, P. Guilloteau, and R. Toullec. 1984. In vivo milk digestion in the calf abomasum. II. Milk and whey proteolysis. Rep. Nutr. Dev. 24:835.
Wang, Q., and K. B. Qvist. 2000. Investigation of the composite system of $\beta$-lactoglobulin and pectin in aqueous solutions. Food Res. Int. 33:683-690.

Weinbreck, F., R. de Vries, P. Schrooyen, and C. G. de Kruif. 2003. Complex coacervation of whey proteins and gum arabic. Biomacromolecules 4:293-303.

Xia, J., and P. L. Dubin. 1994. Protein-polyelectrolytic complexes. Pages 247-271 in Macromolecular Complexes in Chemistry and Biology. P. L Dublin, J. Bock, R. Davis, D. N. Schulz, and C. Thies, ed. Springer-Verlag, Berlin. 